\title{
AKO BYŤ ŠŤASTNÝM NAPRIEK EKONOMICKÉMU BLAHOBYTU
}

\section{Mária Bláhová}

\section{Kl’účové slová:}

št’astný život, ekonomický rast, závislost' na spotrebe, hospodárska kríza, materiálne statky, duchovné hodnoty, prebytková ekonomika

\section{Key words:}

happy life, economic growth, dependence on consumption, economic crisis, material abundance, spiritual values, surplus economy

\begin{abstract}
Abstrakt
V článku podávame pohl'ad na situáciu v súčasnom globalizovanom svete, v ktorom vel'ká čast' obyvatel'stva žije v prebytkových ekonomikách. Podmienky na život a životná úroveň sa výrazne zýšili v porovnaní s minulost'ou a to dokonca aj v chudobných regiónoch. Otázkou zostáva, či materiálny dostatok prináša l'ud'om aj primeraný pocit spokojnosti a št’astia. Uvádzame názory viacerých odborníkov na túto situáciu a závere podávame vlastné zhrnutie aký postoj zaujat' k problematike št'astia v modernej globalizovanej spoločnosti.
\end{abstract}

\begin{abstract}
The paper provides survey on the typical situation in present globalized world, where a great number of population lives in surplus economies. Life conditions as well as living standards have significantly increased in comparison with the past even in the most backward regions. The question to be responded, however is, whether material abundance shares appropriate feelings of happiness and content in people's lives. We propose some interesting standpoints of professionals from different scientific branches. At the end we submit our own approach to the role of happiness in modern globlized societies.
\end{abstract}

\section{Úvod}

Nespočetné výskumy prinášajú rôzne pohl'ady a stále novšie a novšie teórie o tom, čo spôsobuje, že niektorí l'udia, ba celé skupiny alebo národy sú št'astnejšie a ich postoj k životu je v prevažnej miere optimistický a u iných je to naopak. Odborníci z prírodných, ekonomických i humanitných vied sa po stáročia snažili objasnit' v čom tkvie podstata l'udského št'astia, aby mohli vytvorit' určité pravidlá, podl'a ktorých by bolo možné viest' bezproblémový a spokojný život. Problém však spočíval v tom, že sa vedelo len vel'mi málo o tom, čo vlastne robí l’udí št’astnými. Názory na to, čo je št’astie sú vel'mi rôzne a preto ani samotná definícia tohoto pojmu nie je jednoduchá. Rozdielne ju definujú filozofi, psychológovia, lekári, či ekonómovia a ich závery - čo robí l'udí št’astnými - sú taktiež vel'mi odlišné. ${ }^{1}$ Skúmanie pocitov spokojnosti a št'astia sleduje aj pozitívna psychológia, ktorej zakladatel'om je americký profesor Martin Seligman. Podl'a jeho názoru je l'udské št'astie nielen pôžitok, ale je to angažovanie sa a dobré vzt'ahy s l'ud'mi. Št'astie sú aj úspechy a to, či má náš život zmysel. ${ }^{2}$ Dôležité je aj zdravie a osobná sloboda, ktorá sa však chápe v rôznych častiach sveta odlišne.

\footnotetext{
${ }^{1}$ Napr. nemecký filozof E. Kant dokonca tvrdil, že príčinou pocitu nešt’astia nie je možno nič iné ako nedefinovatel'nost' pojmu št’astie. Namiesto toho, aby sme ho získali, nás slová a pojmy od neho vzd’al'ujú.

${ }^{2}$ GRENVILLE-CLEAVE, B., BONIWELL, I.: Rovnica št'astia. s. 106
} 
Súčasná moderná medicína dokáže vedecky zdôvodnit', že za pocity št’astia je zodpovedný hormón serotonín, ktorý sa tvorí v mozgu, a ktorý prenáša chemické odkazy medzi nervovými bunkami a ovplyvňuje zmeny nálady u človeka. Vedci identifikovali aj rôzne varianty génu, ktoré zapríčiňujú väčšiu či menšiu náklonnost' k depresívnym stavom. Z toho potom vyplýva, že u niektorých l'udí je geneticky dané, že ich pohl'ad na svet je optimistickejší a bežné stresové situácie dokážu rýchlejšie prekonat'. Tento typ génov je taktiež zodpovedný za spúšt’ača neprimeraných neurochemických reakcií na stresujúce podnety, či dokonca za sklony k samovraždám. To je však len základ, ktorý sa môže pod vplyvom okolností vyvíjat' viac či menej pozitívne alebo negatívne. Depresia je pravdepodobne najrozsiahlejšou príčinou toho, že sa l'udia cítia nešt'astní, aj ked' rozhodne nie je jedinou príčinou.

Nevyhovujúce životné podmienky a chudoba sa vel'mi často považujú za príčinu nešt'astia a naopak - byt' bohatý - sa vel'mi často považuje za - byt' št’astný. Vzt'ah životných podmienok a sklon k samovražde je jedným z pádnych argumentov voči názoru, že št’astie sa dá kúpit' a čím má človek viac peňazí, tým je št'astnejší. Existuje vel'mi vel'a bohatých l'udí, ktorí sú nešstastní, trpia depresiami, ktoré často končia samovraždami. Epidemiologické (Heretík: Epidemiológia depresie) a demografické štúdie (Montgomery: Measuring Living Standards with Proxy Variables) v rôznych častiach sveta naznačujú niekol'ko možných faktorov, ktoré podporujú vysokú, respektíve nízku mieru sklonov k samovraždám. Patria k nim rizikové faktory (chudoba, nezamestnanot', zvýšená spotreba alkoholu), geografické podmienky (dlhé a nehostinné zimy, oproti slnku a jeho priaznivým účinkom na psychiku), životný štýl (vysoké pracovné nasadenie, tzv. workoholizmus a obava z profesionálneho zlyhania), religiozita ( náboženstvo ako ochranný faktor), užívanie antidepresív (s rastom spotreby antidepresív klesá počet samovrážd), atd’.

To, čo môže mnohých fascinovat' je vzt’ah medzi výškou príjmov a pocitmi št’astia. Ani rozvinuté krajiny sa nárastom svojho bohatstva nestávajú automaticky št’astnejšími. Očakávania l'udí narastajú úmerne s nárastom ich príjmov, ale priama úmera tu nefunguje, ako poukážeme neskôr.

Sú to však len niektoré z celého komplexu d'alších podmienok a príčin, ktoré spôsobujú že l’udia sú alebo nie sú št’astní.

\section{Bohatstvo ako zdroj spokojnosti}

Ako uvádza Ekonomický slovník: „Pojem bohatstvo je historicky a miestne relatívnou kategóriou, môže to byt' stav spoločensky nadpriemerného uspokojovania potrieb alebo súhrn hmotných a nehmotných statkov, v ktorých je nahromadená zhmotnená l’udská práca.“ 3 Klasik a zakladatel' modernej ekonómie, Adam Smith, vo svojom diele Bohatstvo národov uvádza, že „človek je bohatý alebo chudobný podl'a toho, kol'ko si môže dopriat' vecí nevyhnutných pre život a život spríjemňujúcich radovánok.“ " 4 A jeden z najvýznamnejších českých podnikatel'ov svojej doby - Tomáš Bat'a - hlásal, že „, nemôže byt' bohatstvo tam, kde sú l'udia zamestnaní vzájomným podvádzaním. Nemajú čas na vybudovanie hodnôt, teda ani na vytvorenie bohatstva." 5 Podobne ako št'astie, aj bohatstvo má viacero podôb a niekol'ko definícií, ktoré sme uviedli len potvrdzuje, že tento pojem má širokú škálu klasifikácie a interpretácie.

\footnotetext{
${ }^{3}$ Ekonomický slovník. www.euroekonom.sk/poradna/ekonomicky-slovnik/

${ }^{4}$ SMITH, A.: The Wealth of Nations. An Inquiry into the Nature and Causes of the Wealth of Nations. s. 61

${ }^{5}$ Tomáš Bat’a: Obuvník, který dobyl svět. www.dreamlife.cz
} 
Ludové tradície, literatúra a iné umelecké žánre často spájajú št’astie predovšetkým s duchovnými hodnotami. Aj väčšina svetových náboženstiev odsudzuje sklony k hromadeniu materiálnych statkov a nabáda obracat' sa skôr $\mathrm{k}$ veciam duchovným, ktoré by viedli l'udí k pozitívnemu mysleniu aj bez hmotných výhod. Aj odborná literatúra a viacerí kvalifikovaní autori sa venovali téme bohatstva a s ním spájajúcom sa št’astí a spokojnosti.

Harvardský antropológ R. Wrangham, prišiel nedávno s teóriou, v ktorej sa snaží dokázat', čo spôsobilo, že sa l'udia posunuli vo vývoji zo živočíšnej ríše tak, že dokázali ovládnut' svet. Nebolo to len používanie nástrojov ktoré stáli pri ,zrode človeka,“ ale za všetkým je podl’a jeho názoru používanie ohňa. Tým, že si človek podmanil oheň, ktorý ho nielen chránil pred chladom a nebezpečenstvom, prevratným spôsobom zmenil svoje stravovacie návyky. ${ }^{6}$ Varené jedlo má viac kalórií v porovnaní so surovým a je chutnejšie. Jeho konzumácia prinášala našim predkom prvé pocity spokojnosti a št’astia, väčší prísun živín umožnil vývin l'udského mozgu a zmenil spoločenský život - vznikli tak predchodcovia dnešných manželstiev. R. Wrangham zároveň zdôrazňuje, že aj prvé zväzky medzi mužom a ženou neboli založené na sexe, ale na príprave jedla. To, že láska a spokojnost' idú cez žalúdok, má podl'a tejto teórie svoje historické opodstatnenie. Ako tvrdí R. Wrangham, toto bol skutočný moment vzniku l'udského rodu.

Vyvinuli sme sa teda z bytostí, ktoré museli vynaložit' vel'a úsilia na to, aby si zaistili dost' potravy, našli partnera, vychovali deti - a boli št’astní. Táto snaha o prežitie, boj proti hladu bol bojom s nepriaznivými podmienkami, živelnými pohromami a neustálym prekonávaním prekážok, ktoré človeku stáli v ceste v boji s prírodou a klimatickými podmienkami.

Možno už v tých časoch vznikla u našich predkov túžba zabezpečit' seba i svojich blízkych aj na dlhšie obdobie - vytvorit' či nahromadit' si určité bohatstvo, ktorým by tento ciel' dosiahli. V kočovných spoločnostiach však bolo pomerne náročné zhromažd'ovat' a vlastnit' čokol'vek, čo sa nedalo jednoducho prenášat'. Až ked' sa l'udia usadili natrvalo, mohli začat' zhromažd'ovat' majetky, ktoré, ako dúfali, zabezpečia im št'astnejší život. A ked' sa vyvinul systém peňazí, obmedzenie v získavaní majetkov sa úplne vytratilo. Hromadenie peňazí a materiálnych statkov predstavuje poistku „na horšie časy.“ L’udia sa teda snažili predovšetkým o to, aby získali nejaké bohatstvo, ktoré by im spríjemnilo život. Bohatstvo sa odjakživa spájalo so št'astím, aj ked' je známe, že št’astie sa za peniaze kúpit’ nedá.

Druhá polovica dvadsiateho storočia však priniesla aj v tejto oblasti vel'a prevratných zmien. Dve svetové vojny, ktoré zdevastovali predovšetkým Európu, ale zasiahli aj ostatné časti sveta, zmenili poradie hodnôt. Významné vedecko-technické objavy, naštartovanie ekonomík krajín západnej Európy viedli k nebývalému zvýšeniu životnej úrovne obyvatel'stva. Čoraz viac l'udí si mohlo dovolit' vylepšenie svojej úrovne bývania, dovolenky v zahraničných destináciach, pomerne pravidelné obmieňanie vozového parku, atd’. Zároveň získali aj prístup ku kvalitnejšiemu vzdelávaniu pre seba, i pre svoje deti. L'udia, ktorí pracovali, sa mali dobre a zdalo sa, že sú aj spokojní a št’astní. Ich priemerný ročný plat sa od konca druhej svetovej vojny síce neustále zvyšoval, ale miera št’astia nestúpala rovnakým tempom. Príčinou tohto stavu môže byt' skutočnost', že l'udia hodnotia výšku svojho príjmu skôr relatívne než $v$ absolútnych číslach. Teda, ak okrem nás bohatnú aj všetci ostatní, individuálny pocit št’astia sa vel'mi nezvýši.

\footnotetext{
${ }^{6}$ WRANGHAM, R.: Catching Fire: How Cooking Made Us Human. s. 45
} 
Napriek tomu, alebo možno práve preto, sa v 60-tych rokoch minulého storočia v USA a v niektorých d'alších krajinách zdvihla vlna protestov proti konzumnej spoločnosti. Bolo to hnutie „hippies,“ ktorí spolu s niektorými predstavitel'mi populárnej hudby odsudzovali mamon peňazí a svoje št’astie hl'adali v návrate k prírode a v jednoduchom spôsobe života. Aj ked' hnutie hippies malo svoje negatívne stránky, l'udia sa začali zamýšl'at' nad tým, či je materiálne bohatstvo naozaj naplnením št’astia.

\section{Závislost’ na spotrebe}

Ako bolo spomenuté vyššie, l'udstvo po mnohé stáročia svojej existencie vynakladalo nemalé úsilie a bojovalo s nedostatkom obživy a s nepriaznivými životnými podmienkami. Len v ostatných niekol'kých desat'ročiach sa problémy spojené s neustálym bojom o prežitie presúvajú od nedostatku k prebytku. Nikdy predtým v minulosti sa l'udia nemuseli zaoberat' otázkou, či to, respektíve kol'ko toho spotrebujú, neuškodí ich zdraviu.

Dnes je však situácia celkom odlišná. Najväčším svetovým problémom v oblasti výživy už nie sú l'udia, ktorých trápi nedostatok jedla. Práve naopak - sú to tí, ktorí ho majú privel'a. Počet l'udí s nadváhou celosvetovo prevýšil počet podvyživených, dokonca aj v chudobných krajinách. Aj v týchto krajinách sa totiž mení zloženie tradičnej stravy a l'udia čoraz menej času venujú fyzickému pohybu - globalizácia zasiahla aj túto oblast'. Výsledkom je to, že obezita sa rýchlo šíri, zatial' čo hlad pomaly ustupuje. Teda nie hlad, ale prebytok potravín spôsobuje v mnohých prípadoch, že l'udia prestávajú byt' št'astní (tab. 1).

Sme teda svedkami toho, že moderná spoločnost' väčšiny krajín sveta je vystavená a konfrontovaná s prebytkom - a to nielen v oblasti potravín, ale aj iných komodít. Vel'ká čast' sveta žije v takých spoločnostiach, kde funguje prebytková ekonomika a takmer všetky jej odvetvia sú kapacitne pret’ažené. Z toho vyplýva, že je potrebné zaoberat' sa otázkou ako existovat' $\mathrm{v}$ takomto svete prebytku, ktorý pôsobí aj na psychickú stránku l'udí, aby sa s týmito javmi dokázali vyrovnat'. Je vel'mi náročné nepodl'ahnút' lákadlám reklám, ktoré útočia z každej strany, sú mimoriadne sugestívne a vnucujú nám stále novšie a novšie výrobky a služby. Ak nás presvedčia o tom, že ich k svojmu životu naozaj potrebujeme, môže to viest' k zvýšenej frustrácii a pocit št'astia to rozhodne nezvýši.

T. Sedláček vo svojej knihe Ekonomie dobra a zla uvádza, že spotreba je drogou celej našej spoločnosti. ${ }^{7}$ A podobne, ako každá droga, má aj spotreba, pokial' sa vymkne spod kontroly, negatívne dôsledky. Čo teda ženie l'udí za materiálnymi statkami a konzumným spôsobom života, ked' im to neprináša št'astie a spokojnost'? Odpoved' je taká, že sporenie a hromadenie bohatstva sú v l'ud'och historicky zakódované, pretože znamenajú určitú formu zabezpečenia sa do budúcnosti a istotu. Snaha zabezpečit' seba i svoju rodinu vedie mnohých k tomu, že strácajú súdnost' o tom, kde je hranica únosnosti a hromadenie peňazí a d'alších materiálnych statkov sa pre nich stávajú ciel'om samým o sebe. Mnohým l'ud'om to prináša pocit dôležitosti, lebo peniaze im zvyšujú spoločenskú prestíž a umožňujú im využívat' výhody pohodlného života. Len pomerne malé percento týchto l'udí, napriek vysokým príjmom a spoločenským výhodám, zostáva pevne na zemi a dosahovanie vysokých príjmov pre nich neznamená konečný ciel'. Výsledky výskumov tiež naznačujú, že mnohí l'udia, ktorí sa vd'aka zvýšeným príjmom presunuli do vyššej spoločnosti, nedosiahli primeraný pocit spokojnosti a št'astia. $^{8}$

\footnotetext{
${ }^{7}$ SEDLÁČEK, T.: Ekonomie dobra a zla. s. 89

${ }^{8}$ BLÁHOVÁ. M.: Štastie a ekonomický rast - vzájomné vztahy a súvislosti. s. 6
} 
Tabul'ka č. 1

Globálna a regionálna spotreba potravín na jedného obyvatel’a (kcal/na obyvatel’a/na deň)

\begin{tabular}{|c|c|c|c|c|c|c|}
\hline Oblast' & \begin{tabular}{|c|}
$1964-$ \\
1966 \\
\end{tabular} & 1974 - 1976 & $1984-1986$ & $1997-1999$ & 2015 & 2030 \\
\hline Svet & 2358 & 2435 & 2655 & 2803 & 2940 & 3050 \\
\hline Rozvojové krajiny & 2054 & 2152 & 2450 & 2681 & 2850 & 2980 \\
\hline Blízky východ a Severná Afrika & 2290 & 2591 & 2953 & 3006 & 3090 & 3170 \\
\hline $\begin{array}{l}\text { Subsaharská Afrika (s výnimkou } \\
\text { Južnej Afriky) }\end{array}$ & 2058 & 2079 & 2057 & 2195 & 2360 & 2540 \\
\hline $\begin{array}{l}\text { Latinská Amerika a Karibská } \\
\text { oblast' }\end{array}$ & 2393 & 2546 & 2689 & 2824 & 2980 & 3140 \\
\hline Východná Ázia & 1957 & 2105 & 2559 & 2921 & 3060 & 3190 \\
\hline Južná Ázia & 2017 & 1986 & 2205 & 2403 & 2700 & 2900 \\
\hline Industriálne krajiny & 2947 & 3065 & 3206 & 3380 & 3440 & 3500 \\
\hline Krajiny s prechodnou ekonomikou & 3222 & 3385 & 3379 & 2906 & 3060 & 3180 \\
\hline
\end{tabular}

Zdroj: FAOSTAT (2003)

Závislost' na spotrebe sa dá liečit', aj ked' je to vel'mi náročné a väčšina spoločnosti sa jej bráni. Každá odvykacia kúra je spojená s odriekaním a pevnou vôlou. Svoju úlohu tu zohráva aj stupeň vzdelanosti spoločnosti, ale aj vekové kategórie obyvatel'stva, pretože je dokázané, že l'udia s nižším vzdelaním, deti a starí l'udia sú l'ahšie manipulovatel'ní a nedokážu sa vzopriet' nástrahám, ktoré konzumná spoločnost' prináša. Ako d’alej uvádza T. Sedláček, existujú dva spôsoby ako zvýšit' úžitok - nakupovat' stále viac a konzumovat' stále nové veci a dúfat', že to človeku prinesie pocit uspokojenia a št’astia. Druhý spôsob vedie človeka k triezvemu náhl'adu a k uspokojeniu sa s tým čo má, bez ohl'adu na okolie a dokázat' si ten úžitok lepšie uvedomit’. Ak sa človek dostane do zlomových, životohrozujúcich situácií, uvedomí si ako málo vecí potrebuje k tomu, aby prežil a bol spokojný.

Je to ako s pôstom. Naši predkovia vedeli, prečo je potrebné v istých obdobiach obmedzit' jedlo a postit' sa - vedie to k očiste tela a k naštartovaniu organizmu do novej fázy života. Podobne je to aj s materiálnymi statkami - občas je vhodné niektoré veci dennej spotreby vysadit' a po čase si uvedomíme, ako sa tešíme na svoj starý televízor, počítač alebo auto.

Ako sme spomenuli, spotreba je ako droga - čím viac toho človek má, tým viac toho chce a navyše u človeka vzniká pocit, že toho čoraz viac aj potrebuje. Väčšina l'udí si myslí, že ak vymenia staré auto za nové, budú št'astnejší. Je to pravda len do istej miery a ten pocit št'astia je tým kratší, čím viac si toho môžeme dovolit'. To znamená, čím je človek bohatší, tým viac toho paradoxne potrebuje, aj ked' teoreticky by vlastne malo platit', že čím sme bohatší, tým by sme mali byt' aj št’astnejší, pretože budeme toho potrebovat' menej, lebo všetko už máme. Ale v skutočnosti to takto vôbec nefunguje.

T. Sedláček d'alej uvádza, že spotreba by nemala byt' jediným zdrojom št'astia v živote a ak sú naše materiálne potreby saturované, l'udia by si mali uvedomit', že št'astie treba hl'adat' v niečom inom. To je však už individuálna vol'ba každého jednotlivca, navyše podmienená 
celým radom d'alších faktorov, ktoré sú dané rozdielnost'ou jednotlivých kultúr. Nie je to vôbec jednoduché, a preto sa o to mnohí ani nepokúšajú a volia jednoduchšiu cestu hromadenia materiálnych statkov, ktoré často nemajú ani čas si vychutnat', lebo ich vzápätí nahradia niečím iným. Nové veci a nové vzt'ahy dokážu l'udí potešit' a uspokojit' čím d'alej tým kratšiu dobu a v mnohých prípadoch sa s nimi ani nedokážu bližšie oboznámit' a stotožnit', pretože konzumná spoločnost' neustále chrlí nové a lepšie, modernejšie a technicky dokonalejšie tovary.

\section{Kríza ako záchrana}

Ludský vek sa predlžuje, l'udia majú vo všeobecnosti viac vol'ného času na svoje zál'uby, na svoje rodiny a priatel'ov a život im spríjemňujú výdobytky modernej techniky. Aj s tým však vzniká problém, pretože l'udia často nedokážu s vol’ným časom zaobchádzat' efektívne, nevedia ho využit' tak, aby boli št'astní a spokojní.

To, že s tým môže byt' problém, odhadol už v tridsiatych rokoch minulého storočia britský ekonóm J. M. Keynes. Vo svojej eseji Ekonomické možnosti našich vnukov totiž poznamenal, že napriek dlhému vývoju v dejinách l'udstva, najzávažnejšie pozitívne zmeny v priemernej životnej úrovni l'udí nastali až po nástupe priemyselnej revolúcie (18. storočie). Ako tvrdí Keynes, napriek zvýšeniu počtu obyvatel'stva, sa životná úroveň v USA a v Európe zvýšila od r. 1700 štvornásobne. Keynes d'alej predpovedal, že tento trend bude pokračovat' v nasledujúcich sto rokoch a životná úroveň sa zvýši štvor- až osemnásobne. Výsledkom by, podl'a Keynesa, bolo to, že permanentný boj za prežitie, ktorému l'udstvo muselo čelit' od začiatku svojej existencie, prestane vlastne existovat'. Namiesto toho, tvrdí Keynes, nastane reálny a trvalý problém ako využit' túto vol'nost' a dokázat' sa oslobodit' spod ekonomických tlakov tak, aby l'udia dokázali žit' rozumne, zmysluplne a boli spokojní a št’astní. ${ }^{9}$

Zdá sa, že Keynesove odhady boli celkom presné - vel'ká čast' sveta žije v prebytkovvých spoločnostiach a l'udia riešia celkom iné problémy ohl'adne št’astného a spokojného života ako naši predkovia. Napriek tomu, že svetová ekonomická kríza priniesla problémy a l'udia šetria viac, v mnohých spoločnostiach sa l'udia stále riadia tým, že chcú mat' viac a nedokážu si pripustit', že by kríza mohla postihnút' ich alebo ich rodiny. Pritom už starogrécki filozofi tvrdili, že lepšie je mat' menej, pretože čím toho má človek viac, tým menej je slobodný. Mnohí si však dnes myslia, že platí pravý opak - čím viac toho majú, tým sú slobodnejší. Výsledkom toho je v mnohých prípadoch to, že sa človek naháňa celé dni v práci, ktorú často neznáša, aby si mohol kúpit' veci, ktoré vlastne ani nepotrebuje. A to všetko len preto, lebo si nahovára, že potom už bude št'astnejší a spokojnejší a nedokáže sa zastavit'. Zvyčajne sa musí stat' niečo vel'mi významné, čo by ho primälo k prehodnoteniu postojov. Môže to byt' nečakaná choroba či iná tragédia v blízkom okolí, strata zamestnania, alebo aj ekonomická kríza. L'udstvo potrebuje krízu k tomu, aby sa zmenilo. Je samozrejmé, že tá kríza by mala byt' umiernená a dávkovaná postupne. To je však situácia, ktorú nikto nedokáže naplánovat' vopred a tobôž zariadit'.

Britský ekonóm T. R. Malthus na prelome 18. a 19. storočia uviedol svoju teóriu, v ktorej tvrdil, že s rastom príjmov a bohatstva l'udí dôjde k zvýšeniu populácie, pretože si budú môct' „dovolit““ mat' viac detí, ktoré dokážu uživit'. Viedlo by to však ku geometrickému nárastu populácie, v porovnaní s lineárnym rastom potravín. To by mohlo mat' katastrofické následky,

\footnotetext{
${ }^{9}$ KEYNES, J. M.: Economic Possibilities for Our Grandchildren. s. 360-364
} 
ktoré by dokázali vyriešit' občasné vojny, hladomor alebo hospodárske krízy. T. R. Malthus ich horlivo obhajoval ako prirodzenú reguláciu populácie a dosiahnutia rovnováhy. ${ }^{10}$

Súčasný vývoj však ukazuje, že rastúce bohatstvo, vyššia životná úroveň a prosperita vedú skôr k znižovaniu pôrodnosti. Americký ekonóm, nositel' Nobelovej ceny G. S. Becker to zdôvodňuje tým, že dopyt po vel'kých rodinách sa znižuje preto, lebo s rastúcim bohatstvom spoločnosti sa čas vynaložený na starostlivost' o deti stáva drahším a stúpa dôležitost' vzdelania, ktorá stimuluje rodičov, aby investovali do vzdelávania svojich detí viac, čím sa náklady rodín d’alej zvyšujú. ${ }^{11}$ Záver je teda, podl’a G. S. Beckera, presne opačný ako predpovedal T. R. Malthus. Ak zoberieme do úvahy, že kritériom pre obnovu generácií je priemerná pôrodnost' 2,1 diet'at'a na jednu rodinu, táto hranica pôrodnosti v súčasnosti klesla nielen $\mathrm{v}$ rozvinutých, ale aj $\mathrm{v}$ mnohých krajinách tretieho sveta, napr. v Brazílii alebo Thajsku. Vysoká pôrodnost' sa drží stále v Indii a v krajinách subsaharskej Afriky. Teoreticky z toho vyplýva, že z hrozby prel'udnenia planéty a nedostatku potravín (Malthus), sme sa dostali až k obavám o samotnú existenciu l’udstva. Východisko z tejto situácie nie je jednoduché, pretože obhajovat' vojny v žiadnom prípade nechceme, ale hospodárskym krízam sa nevyhneme.

V tomto článku sa však nechceme zaoberat' ekonomickými dôsledkami krízy, ale zamerat' sa skôr na sociologické aspekty v zmene správania l'udí a poukázat' na to, ako sa s rastúcou prosperitou mení správanie l’udí a ich pocity št’astia a spokojnosti.

Ak porovnáme ako sa zmenili pomery v spoločnosti, v ktorej žijeme za ostatných dvadsat' rokov, je to obrovská zmena. Ludia síce vtedy zarábali menej, ale vel'ké platové rozdiely neexistovali. Vlastnit' auto bolo istým luxusom, dnes to patrí k pomerne bežnej výbave domácností. L'udia sa dnes porovnávajú nie s tým, či auto majú, ale akú značku vlastnia, resp. ako často ho menia za nové. Podobne je to aj s inými komoditami, či využívaním služieb. ${ }^{12}$ Záleží na porovnávaní a aké aspekty sa pri porovnávaní berú do úvahy - to všetko hrá významnú úlohu pri pocitoch št’astia. Mnohí l'udia sa totiž nedokážu porovnávat's podobnou sociálnou skupinou, ale majú prehnané, pre nich neuskutočnitel'né a nedosiahnutel'né nároky. Tie vedú potom $\mathrm{k}$ frustrácii a nespokojnosti. A pritom je pravdou to, že prudké zmeny $\mathrm{v}$ náraste pocitov št'astia nastávajú len u najnižších príjmových vrstiev obyvatel'stva.

Ak sa človek dostane z absolútnej chudoby na úroveň, ktorá ho posúva nad hranicu chudoby, vtedy prežíva najväčšie pocity št'astia. Tento fakt je prakticky totožný vo všetkých častiach sveta, aj ked' hranica chudoby je v rôznych krajinách výrazne odlišná. Je síce náročné, až takmer nemožné porovnávat' pocity št’astia u l’udí, ktorí pochádzajú z rôznych kultúr, ale fakt, že väčší majetok prináša viac št’astia iba na nízkych príjmových úrovniach, platí prakticky všade vo svete, bohaté krajiny, napr. USA, Japonsko či Vel'kú Britániu nevynímajúc. L’udia v týchto krajinách sú v priemere bohatší ako napr. obyvatelia Thajska alebo Mexika, ale št'astnejší rozhodne nie sú. ${ }^{13}$

Tak, ako to predpovedal J. M. Keynes v tridsiatych rokoch minulého storočia platí, že bohaté krajiny už dospeli k určitému zlomovému bodu a pocity št’astia a spokojnosti sa postupne

\footnotetext{
${ }^{10}$ MALTHUS, T. R.: An Essay on the Principle of Population. s. 18

${ }^{11}$ BECKER, G. S.: Fertility and the Economy. s. 185-201

12 Je zaujímavé, že v bývalých socialistických krajinách východnej Európy sa tesne po začiatku procesov demokratizácie zaznamenala nižšia úroveň št’astia ako pred ním. Vysvetl'uje sa to tým, že v bývalom režime mali l'udia malé očakávania, ktoré sa po jeho páde výrazne zvýšili, ale realita značne zaostávala za očakávaniami.

${ }^{13}$ BLÁHOVÁ. M.: Št’astie a ekonomický rast-vzájomné vzt’ahy a súvislosti. s. 3
} 
dostanú do popredia záujmu politikov i ekonómov. Hédonistická psychológia, alebo veda o pocitoch št'astia, si spolu s ekonomickou teóriou št'astia získavajú čoraz väčšiu podporu aj medzi odbornou verejnost'ou.

\section{Morálna zodpovednost'}

Podpora ekonomického rastu však zostáva stále hlavným ciel'om hospodárskej politiky väčšiny štátov. Aj ked’ je stále zrejmé, že zvýšený rast národných ekonomík vedie vo väčšine krajín k vyššej životnej úrovni obyvatel'stva, v ostatných rokoch sa kult hrubého domáceho produktu stretáva aj s nepriaznivou kritikou. Mnohí v nej totiž vidia príčinu prehnaného drancovania prírodných zdrojov, ktoré sú v mnohých prípadoch zastieracím manévrom a ospravedlnením pre presadzovanie záujmov niektorých skupín hospodárskej sféry. Výsledkom je však to, že bohatší sa stávajú bohatšími a prehlbuje sa nerovnost' medzi l'ud'mi. Ďalšou príčinou kritiky HDP je to, že do hrubého domáceho produktu krajiny sa započítavajú aj výdaje, ktoré súvisia s vyslovene negatívnymi javmi, ako je pocit ohrozenia, bezpečnosti, zvýšený počet automobilových a iných nehôd, apod. Všetky tieto javy podporujú ekonomický rast v tom, že obyvatelia investujú viac prostriedkov, aby si zabezpečili zvýšenú ochranu a bezpečnost', ale pocit spokojnosti a št'astia sa u nich nezvyšuje. Práve naopak, aby ochránili svoje rodiny a svoje majetky, najímajú si bodyguardov, ktorí ich majú v prípade potreby ochránit'. Zvyšuje to ekonomický rast a dokonca aj zamestnanost', ale dokážu l'udia takto viest' plnohodnotný, št'astný a spokojný život? V krajinách s autoritárskym režimom je táto skutočnost' bežná a vo svete zvýšeného nebezpečenstva teroristických útokov sa tento jav prejavuje v čoraz väčšej miere aj vo vyspelejších krajinách.

Podl'a profesora politickej ekonómie na harvardskej univerzite B. M. Friedmana, je „ekonomický rast podstatný a nevyhnutný, pre väčšiu príležitost', toleranciu rôznosti, spoločenskú mobilitu, záväznú poctivost' a oddanost' demokracii“. ${ }^{14}$ Ako d'alej uvádza B. M. Friedman, v dobách rozvoja majú štáty sklony k liberalizácii - rozširujú práva občanov, znižujú obmedzenia a viac prispievajú tam, kde je to potrebné. Ked' nastane stagnácia, prejavujú väčšie tendencie priklonit' sa $\mathrm{k}$ autoritárstvu. Hospodársky rast, podl'a neho, nielenže zvyšuje životnú úroveň a umožňuje vel'korysejšiu sociálnu politiku, ale vyvoláva v l'ud'och viac optimizmu voči budúcnosti, čo zase zvyšuje pocity spokojnosti a št’astia. Je to zaujímavý pohl'ad, aj ked' sa autor zameral predovšetkým na analýzy vyspelých krajín, predovšetkým USA, Vel'kej Británie, Francúzska a Nemecka. B. M. Friedman zároveň tvrdí, že akékol'vek znižovanie rastu by poškodilo predovšetkým zaostalejšie časti sveta, pretože by sa spomalil globálny rast. Jedným dychom však dodáva, že trhová ekonomika ešte automaticky nezaručí ani rast, ani sociálnu spravodlivost', ba ani hospodársku efektivitu. Na dosiahnutie týchto ciel'ov sa vyžaduje významná zaangažovanost' zo strany vlád jednotlivých krajín. Politici však myslia politicky a ich pohl'ad býva často krátkodobý a populistický. Preto sa môže stat', že dokážu pochovat' aj najlepšiu víziu o prepojení ekonomického rastu a zvýšenia blahobytu a št’astia. S niektorými názormi $\mathrm{B}$. M. Friedmana by sa dalo polemizovat', ale jeho pohl'ad na rast pocitov št'astia a spokojnosti u l'udí je rozhodne zujímavý. 15

\footnotetext{
${ }^{14}$ FRIEDMAN, B. M.: The Moral Consequences of Economic Growth. s. 135

${ }^{15}$ V amerických dejinách je niekol'ko príkladov, ktoré tvrdenia Friedmana priamo popierajú. Napr. ked' v r. 1893 vypukla v USA hospodárska kríza, tlak v prospech liberálnych reforiem neprestal - hnutia na podporu zavedenia všeobecného hlasovacieho práva, či zvýšenie sociálnej spravodlivosti pokračovali vo svojej intenzite.
} 


\section{5. Št’astné národy}

Samotná myšlienka, že št’astie je pre zdravý rozvoj spoločnosti dôležité, nie je vonkoncom nová. Thomas Jefferson (1743-1826), ktorý stál pri vzniku Spojených štátov, kládol úsilie o dosiahnutie št’astia na rovnakú úroveň ako slobodu a demokraciu v živote krajiny. Od tých čias táto téma rezonuje viac alebo menej $\mathrm{v}$ rôznych častiach sveta podl’a momentálnej situácie a vývoja v jednotlivých regiónoch.

Niektoré inštitúcie sa snažia zaviest' iné meradlá hospodárskeho rozvoja ako je hrubý domáci produkt - napr. ukazovatel' skutočného pokroku (genuine progress indicator), udržatel'ný ekonomický blahobyt (sustainable economic welfare), index št'astia (happiness index), a iné. $\mathrm{Na}$ ich stranu sa často prikláňajú aj renomovaní ekonómovia, ktorí tvrdia, že keby sa krajiny odklonili od honby za materiálnymi statkami, zostalo by viac priestoru na duchovné veci, ktoré by obyvatel'ov viedli k pozitívnejším náladám.

Aj myšlienka zavedenia indexu národného št’astia ( national happiness index), ktorú pre svoju krajinu zaviedol bhutanský král', je zaujímavá. Je diskutabilné, či táto krajina, ktorá zápasí s problémami rastu svojej ekonomiky, ako aj úrovne demokracie, dosiahne výraznejší pokrok zavedením takéhoto ukazovatel'a, hoci sa snaží, aby ju v tomto smere nasledovali aj d’alšie štáty sveta.

A ako je to so št’astnými, či menej šstastnými národmi? Adrian White z Leicesterskej univerzity vo Vel'kej Británii, vytvoril štúdiu najšt'astnejších a najnešt’astnejších národov a zostavil tzv. svetovú mapu št'astia. Použil pri tom údaje z rôznych medzinárodných organizácií a vzorku 178 krajín z celého sveta (tab. 2). Výsledky priniesli pomerne prekvapujúce fakty, že mnohé vyspelé krajiny (USA - 23., Nemecko - 35., Vel'ká Británia 41., Japonsko - 90....) sa umiestnili na nižších miestach v porovnaní s takými krajinami ako napr. Bhutan - 8., Kostarika - 13., Seychelské ostrovy - 20. Na druhej strane spektra však nie sú výraznejšie rozdiely v porovnaní s inými výsledkami výskumov - na posledných troch miestach sú najchudobnejšie africké štáty, v ktorých prevláda okrem ekonomickej aj politická nestabilta. Závery, ku ktorým A. White dospel sú, že pri posudzovaní spokojnosti kladú l’udia väčší dôraz na zdravie ako na blahobyt a vzdelanie. Tieto tri faktory však zároveň hrajú pri pocitoch št’astia najväčšiu úlohu.

Tabul'ka č. 2

\begin{tabular}{|l|l|}
\hline \multicolumn{1}{|c|}{ Najšt'astnejšie krajiny } & \multicolumn{1}{c|}{ Najmenej št'astné krajiny } \\
\hline 1. Dánsko & 178. Burundi \\
\hline 2. Švajčiarsko & 177. Zimbabwe \\
\hline 3. Rakúsko & 176. Demokratická republika Kongo \\
\hline 4. Island & 175. Moldavsko \\
\hline 5. Bahamské ostrovy & 174. Ukrajina \\
\hline 6. Fínsko & 173. Sudan \\
\hline 7. Švédsko & 172. Arménsko \\
\hline 8. Bhutan & 171. Turkménsko \\
\hline 9. Kanada & 170. Bielorusko \\
\hline 10. Írsko & 169. Gruzínsko \\
\hline 77. Česká republika & \\
\hline 129.Slovenská republika & \\
\hline
\end{tabular}

Zdroj: A. White, University of Leicester (2007) 
Organizácia pre hospodársku spoluprácu a rozvoj (OECD) pravidelne uverejňuje výsledky výskumov na základe 30 posudzovaných kritérií, ako sú napr.: ekonomický rozvoj, školstvo, zdravie, zamestnanost', sociálny systém, bezpečnost', všeobecná spokojnost' l'udí so svojím životom, atd'. Podl'a nich, medzi najšs'astnejšie a najspokojnejšie národy patria škandinávske krajiny (tab. 3). V týchto krajinách vo všeobecnosti prevláda vysoká miera vzájomnej dôvery medzi l'ud'mi, ako aj dôvery obyvatel'stva k vládam svojich krajín.

\section{Tabul'ka č. 3}

\begin{tabular}{|l|}
\hline 1. Dánsko \\
\hline 2. Nórsko \\
\hline 3. Holandsko \\
\hline 4. Švajčiarsko \\
\hline 5. Rakúsko \\
\hline 6. Izrael \\
\hline 7. Fínsko \\
\hline 8. Austrália \\
\hline 9. Kanada \\
\hline 10.Švédsko \\
\hline 24.Česká republika \\
\hline 29.Slovenská republika \\
\hline Zdroj: OECD (2012)
\end{tabular}

Pre pocity št’astia a spokojnosti je pre obyvatel'ov Európskej únie dôležité zdravie, dobré rodinné zázemie, blízke vzt'ahy medzi priatel'mi, spokojnost' v zamestnaní, v komunite, v ktorej l'udia žijú, náboženstvo, dobrý zdravotný stav a osobná sloboda. Zdrojom najväčšej neistoty obyvatel'stva únie je hrozba nezamestnanosti, stúpajúce životné náklady a životná úroveň na dôchodku. Vysoko sa cení vyváženost' medzi prácou a súkromím, pretože l'udia s vyššími príjmami trávia ovel'a viac času v práci, sú vystavení vyššiemu stresu a namiesto toho, aby sa venovali rodine alebo odpočinku, pracujú. Zvyšuje sa u nich podráždenost', hnev a napätie, ktoré rozhodne nevedú k nárastu pocitov št’astia či spokojnosti.

Tzv. Správa o stave štastia vo svete (World Happiness Report), ktorú pre OSN vypracoval Earth Institute, Columbia University poukazuje na to, ako sú l'udia v jednotlivých krajinách spokojní so svojím životom (tab. 4). Výskumu sa zúčastnilo 156 krajín sveta a vyplýva z neho, že najšt'astnejšie krajiny sa nachádzajú na severe Európy, prevažne v Škandinávii. Tie najmenej št’astné sú takmer všetky zo Subsaharskej časti Afriky. Zarážajúce je nízke hodnotenie Bulharska (147.), ktoré je členským štátom Európskej únie. Nie je to len bohatstvo a vysoký príjem na jedného obyvatel'a (toto bolo zdôraznené viackrát), ktoré robia l'udí št'astnými. Zamestnanost', predovšetkým tá dlhodobá, ako aj istota zamestnania, ktoré spolu s ekonomickou stabilitou, sociálnymi istotami, vysokou mierou politickej slobody a absencia, resp. minimálna korupcia - tvoria najdôležitejšie kritériá pri určovaní determinantov št’astia. 
Tabul'ka č. 4

\begin{tabular}{|l|l|}
\hline \multicolumn{1}{|c|}{ Najšs'astnejšie krajiny } & \multicolumn{1}{c|}{ Najmenej št'astné krajiny } \\
\hline 1. Dánsko & 156. Togo \\
\hline 2. Fínsko & 155. Benin \\
\hline 3. Nórsko & 154. Stredoafrická republika \\
\hline 4. Holandsko & 153. Sierra Leone \\
\hline 5. Kanada & 152. Burundi \\
\hline 6. Švajčiarsko & 151. Komory \\
\hline 7. Švédsko & 150. Haiti \\
\hline 8. Nový Zéland & 149. Tanzánia \\
\hline 9. Austrália & 148. Demokratická republika Kongo \\
\hline 10.Írsko & 147. Bulharsko \\
\hline 36.Česká republika & \\
\hline 55.Slovenská republika & \\
\hline
\end{tabular}

Zdroj: UN Commissioned Report by Earth Institute, Columbia University (2012)

\section{Záver}

L'udia sa odjakživa snažili, aby bol ich život št'astný a spokojný. V rôznych etapách historického vývoja, pristupovali k naplneniu tohoto ciel'a rozličnými spôsobmi. Hromadenie materiálnych statkov a peňazí bolo vždy spájané s predstavou št’astia a spokojnosti. Aj ked' je pravda, že bohatí l'udia sú vo všeobecnosti spokojnejší, neplatí to vždy a ako sme poukázali na začiatku, ani bohatstvo nezaručuje automaticky št'astný život a mnohí bohatí l'udia trpia depresiami a majú sklony k samovraždám.

Aj ked' sa hromadenie peňazí zvyčajne odsudzuje, aj peniaze môžu niekedy prinášat' št'astie. Nesmú sa však stat' ciel'om samým o sebe, ale mali by slúžit' na naplnenie vel'korysejších a vznešenejších ciel'ov. Príkladom sú niektorí bohatí investori, ktorí pochopili, že na vlastný spokojný a št'astný život im stačí určitá čast' ich majetku. Warren Buffet, či Bill Gates dali svojmu životu iný zmysel - ich peniaze môžu zmenit' životy mnohých chudobných l'udí, ktorí by bez ich pomoci zostali bez vzdelania či bez zdravotnej starostlivosti. Je to len jeden príklad z mnohých, ako byt' št'astný napriek blahobytu.

Št'astie je jedným z vel'kých hesiel novoveku (Be happy), pretože vzbudzuje vo všeobecnosti v l'ud'och viac optimizmu a celkového pozitívneho postoja k svetu ako melanchólia, smútok, alebo depresie. Preto sú reklamy plné väčšinou mladých, št’astných a spokojných l'udí, ktorým sa darí vo všetkom - v práci i v súkromí. To je imidž súčasnej spoločnosti, ktorá láka l’udí do svojich pascí, o ktorých sme hovorili. Nájst' vyváženost' medzi mierou únosnosti hmotného blahobytu a vhodným trávením vol'ného času, ktoré súvisia aj s predlžovaním l'udského života vd’aka modernej medicíne, si vyžaduje istú dávku sebareflexie.

Rôzne teórie a výskumy sa snažia vniest' do tejto problematiky rôzne aspekty a dobré rady. Ekonomická teória št'astia (happiness economics) a determinanty št'astia (determinants of happiness) hl'adajú nové objasnenia pre nové možnosti št’astného života l'udí v modernej spoločnosti. Ich kritici však poukazujú na to, že zavedenie ,indexu št’astia“ ako matematicky meratel'nej veličiny je nemožné a slúži len na pochybné napíňanie ambícií politikov. Na druhej strane jej zástancovia tvrdia, že aj ked' sú takéto hodnotenia nepresné, predsa len 
výraznejšou mierou hodnotia úroveň pokroku a rozvoja a vyvolávajú užitočné diskusie na tému št’astný a spokojný život.

Jednoznačný recept alebo návod na št’astie nejestvuje. Kvalita spoločnosti sa určuje aj podl'a miery jej súdržnosti. Je to kombinácia dôvery, vzájomnosti, pomoci a dobrovol'nosti. V niektorých krajiných je dôvera v iných vel'mi nízka (Turecko 7\%), v iných je vysoká (Dánsko 68\%). ${ }^{16}$ Ako ukázali výsledky výskumov renomovaných svetových organizácií, na popredných miestach št’astných národov sa pravidelne umiestňujú škandinávske krajiny. $\mathrm{K}$ najšt’astnejším národom už dlhodobo patria Dáni.

Ani krajiny s vel'kými rozdielmi medzi bohatými a chudobnými nepatria medzi menej št’astné ako tie, kde je bohatstvo rozdelené rovnomernejšie. Ako to predvídal Keynes, vyspelé západné krajiny už dosiahli bod zvratu a za ostatných štyridsat' rokov sa, napriek zvyšujúcej prosperite, pocity št’astia u ich obyvatel'ov nezvyšujú, skôr naopak, stagnujú, alebo klesajú. Preto sa v post-industriálnej spoločnosti, pocity št'astia a spokojnosti dostávajú aj do pozornosti politikov.

Môžeme teda konštatovat', že blahobyt je síce dobrá vec, ale ekonomický rast sám o sebe celkom iste nezaručuje ani vysokú kvalitu života, ani pocity št'astia u l'udí. Za určitou príjmovou hranicou (ktorá je však vel'mi individuálna), všetko navyše už neprináša št’astie, ale len komfort. Peniaze majú pomôct' l'ud'om, aby žili dôstojne. Je však vel'mi náročné určit' limity dôstojnosti. Aj bohatí l'udia a prosperujúce krajiny majú svoje nenaplnené ambície mat' stále viac - a práve to ich brzdí v št’astí. Podl'a nášho názoru, svoju úlohu v tomto zohráva aj príslušnost' $\mathrm{k}$ určitej kultúre, resp. kultúrne rozdiely, na základe ktorých sa l’udia zarad'ujú do navzájom odlišných skupín. Odlišné kultúry majú vd’aka svojim odlišným hodnotám a životným ciel’om aj odlišný prístup ku št’astiu. To následne ovplyvňuje vyjadrenia jednotlivcov o št’astí či spokojnosti v ich živote. Navyše, vel'mi sa líšia aj podnety, ktoré l'ud'om z rôznych kultúr prinášajú št’astie a spokojnost'. Základné potreby majú všetci l'udia rovnaké, avšak navzájom sa odlišujú spôsobom ich uspokojovania. Každodenný výber a rozhodovanie im umožňuje ich vlastný systém hodnôt. Z hl'adiska pocitu št’astia je vel'mi dôležité, či sú hodnoty l'udí a ich správanie v súlade.

V závere by sme chceli zdôraznit', že téma št'astia a spokojnosti v živote l'udí i celej spoločnosti je aktuálna. Aj ked' sa zdá, že krajiny musia v súčasnosti čelit' vážnejším problémom ako tomu, či sú l'udia št'astní alebo spokojní, považujeme túto oblast' skúmania za dôležitú, pretože podl'a nášho názoru, št’astní a spokojní l’udia dokážu l'ahšie odolávat' problémom a nástrahám, pred ktoré ich dnešná doba stavia.

\section{Literatúra:}

[1] BECKER, G. S. Fertility and the Economy. In : Journal of Population Economics. Volume 5, Number 3. 1992, s. 185 - 201.

[2] BLÁHOVÁ, M. Štastie a ekonomický rast - vzájomné vztahy a súvislosti. In: Ekonomika a management [vědecký online časopis]. http://www.ekonomikaamanagement.cz. Praha : Fakulta podnikovohospodářská, Vysoká škola ekonomická v Praze, 2008. - ISSN 1802-8934. - č. 3.

[3] Ekonomický slovník. www. euroekonom.sk/poradna/ekonomicky-slovnik/

\footnotetext{
${ }^{16}$ GRENVILLE-CLEAVE, B., BONIWELL, I.: Rovnica štastia. s. 24
} 
[4] FRIEDMAN, B. M. The Moral Consequences of Economic Growth. 1. vyd. New York: A. A. Knopf, 2005, 570 s. ISBN 978-1-4000-9571-1.

[5] GRENVILLE-CLEAVE, B., BONIWELL, I. Rovnica štastia. Elwin Street Limited: Eastone Books. 2009, 144 s. ISBN 978-80-8109-094-3.

[6] HERETÍK, A. Epidemiológia depresie. www.mediforum.sk

[7] KEYNES, J. M. Economic Possibilities for Our Grandchildren. In: Essays in Persuasion. 1. vyd. New York: W.W. Norton \& Co. Inc., 1963, s. 358-373. ISBN 0-39300190-3.

[8] MALTHUS, T. R. An Essay on the Principle of Population. 4. vyd. New York: Oxford University Press, Inc. New York, 2008, 172 s. ISBN 978-0-19-954045-7.

[9] MONTGOMERY, M. R., GRAGNOLATI, M., BURKE, K., PAREDES, E. Measuring Living Standards with Proxy Variables. www.popcouncil.org.pdf

[10] SEDLÁČEK, T. Ekonomie dobra a zla. 1. vyd. Praha: Nakladatelství 65. pole, 2009, 272 s. ISBN 978-80-903944-3-8 2009.

[11] SMITH, A. The Wealth of Nations. An Inquiry into the Nature and Causes of the Wealth of Nations. Digireads.com Publishing. 576 s. ISBN 1-4209-3206-3.

[12] Tomáš Bat'a: Obuvník, který dobyl svět. URL http:// www.dreamlife.cz/svet-uspesnych/

[13] TOMKINS, R. How to Be Happy. In: Financial Times Weekend. 08.03. 2003.

[14] WHITE, A. Psychologist Produces the First-Ever World Map of Happiness. Science Daily, 14. 11. 2006. s. 30-35.

[15] WRANGHAM, R. Catching Fire: How Cooking Made Us Human. 1. vyd. New York: Basic Books, 2009, 309 s. ISBN 978-0-465-01362-3.

JEL Z 13

PhDr. Mária Bláhová, PhD.

odborná asistentka Katedry anglického jazyka

Fakulta aplikovaných jazykov

Ekonomická univerzita v Bratislave

Dolnozemská 1/b, 85235 Bratislava 5

Slovenská republika

majablahova@gmail.com 